\title{
The Irreplaceable Books of John Cawte Beaglehole
}

\author{
Dan Scudder, Victoria University Wellington, New Zealand
}

\begin{abstract}
John Cawte Beaglehole (1901-1971) is a renowned New Zealand historian who left behind masses of correspondence, notes, and artifacts. These records reveal a special relationship between Beaglehole and his library of books. Specific examples and his personal insights reveal how books inspired and expressed Beaglehole emotionally. In this Paper I will relay how books connected emotionally with Beaglehole, while also exploring the unique emotional potential of books.
\end{abstract}

Keywords: J.C. Beaglehole, Archive, Emotion

\section{Introduction}

TOHN CAWTE BEAGLEHOLE was born in Wellington, New Zealand in 1901 and grew up in his family home at 49 Hopper Street. Here he became exposed to his parents love of books, both for reading and for collecting. This paper gives a description of Beaglehole's library as it existed at the time of his death in 1971 by analysing data through a computer visualisation program that plots the books according to their characteristics, for example according to author or publishing date. The focus of this exploration is on the relationship between Beaglehole and his books as displayed by the overarching trends that are revealed by the software, where a connection is revealed between Beaglehole and the ideas that his books contain. This paper studies the relationship between the owner and his books and is intended to allow designers and book historians to gain an understanding of the complex and intricate connection created between readers and their books in a period where a flood of electronic reading devices and digital books are entering the market and peoples lives. A clearer understanding of the emotive relationships we have with the carriers of text we read is essential for designing future books and devices that connect with readers, as well as commercial success in a new market. This point is made by Don Norman, author of Emotional Design: Why we love (or hate) everyday things, in relation to emotive design and its success. ${ }^{1}$ As well as the practical side of matters this study attempts to give recognition to our more irrational human habits.

It is the text and the book together that create the experience of reading, as author Roger Chartier says, "One must state that the forms produce meaning and that a text, stable in its letter, is invested with a new meaning and status, when the mechanisms that make it available to interpretation change." 2 A book is unique due to this weave between the text and its carrier. So when books are collected it is about more than just the object of the book. In The Meaning of Things, Mihaly Csikszentmihalyi and Eugene Rochberg-Halton explore the

\footnotetext{
${ }^{1}$ Don Norman, Emotional Design: Why we love (or hate) everyday things, (New York: Basic Books, 2005), 5360 .

${ }^{2}$ Roger Chartier, The Order of Books: readers, authors and libraries in Europe between the fourteenth and eighteenth centuries, (Cambridge: Cambridge University Press, 1994), 3.
}

The International Journal of the Book

Volume 7, Number 3, 2010, http://www.Book-Journal.com, ISSN 1447-9516

(C) Common Ground, Dan Scudder, All Rights Reserved, Permissions:

cg-support@commongroundpublishing.com 
connections made between objects in the domestic environment and how they relate to their owners. In the study, books were significant in the representation of ideals "Twenty-Seven percent of all the meanings referring to the embodiment of ideals involved books, over twice the number of any other object in this category... the theme that emerges is that books, more than any other kind of objects, are special to people because they serve to embody ideals and to express religious and professional values." In his essay "Unpacking my Library: a talk about book collecting' Walter Benjamin directs our attention not just to the collecting of his books but to the relationships he has developed with them. As Benjamin aptly states "Ownership is the most intimate relationship that one can have to objects. Not that they come alive in him: it is he who lives in them." This relationship is a dynamic connection that displays the owners characteristics that can not be shown otherwise. This relationship may be the reason why some of our childhood books are so difficult to throw out, or why it is all to easy to do away with other books.

This study makes use of the resources available to first, visualise the library and then make meaning of the results. A bibliography of Beaglehole's library with his characteristic signing inside the front covers of the books allows comparisons to be made between his library and events in his life. Correspondence available from the New Zealand Electronic Text Center between Beaglehole and his family during the period of 1926 to 1929, while he was studying toward his $\mathrm{PhD}$ at the London School of Economics gives context as well as a primary account of his relationship to the books collected in an important period of his life. This lively correspondence illuminates Beaglehole's personality, and in doing so, also his passion for books. A life of Beaglehole Cawte Beaglehole: New Zealand Scholar, written by Beaglehole's second son Tim Beaglehole, gives a comprehensive account of Beaglehole's life. The biography reveals Beaglehole's books in his life that give meaning to the bibliography. Additional to his correspondence and biography is a notebook Beaglehole used between the years of 1918 and 1926. This notebook contains lists of books he read and purchased in that period, showing a small glimpse of Beaglehole's buying and reading habits. Using graphing software Ggobi a visual representation is created from the list of Beaglehole's library that allows a holistic view of Beaglehole's books to be compared to his life. By using this method it is the relationship between Beaglehole and his books that becomes the focus, rather than the books themselves. The results from the graphs allow conclusions to be drawn about the elusive characteristics of the books and why certain books collected through his life remained in the collection.

\section{John Cawte Beaglehole and his Irreplaceable Library}

John Cawte Beaglehole is best known for his work on James Cook's journals. This work consisted of four volumes that eventually earned him the Order of Merit in 1970, a year before his death in 1971. Beaglehole's close friends and family fondly recall his passion for books. ${ }^{5}$ This stems from Beaglehole's parents, Jenny and Ernest Beaglehole who were both a major influence on Beaglehole and his book habits. Beaglehole's father collected books and had

\footnotetext{
${ }^{3}$ Mihaly Csikszentmihalyi and Eugene Rochberg-Halton, The Meaning of Things: Domestic Symbols and the Self, (Cambridge: Cambridge University Press, 1981), 71.

${ }^{4}$ Walter Benjamin, 'Unpacking My Library' in One Way Street: And Other Writings, (England: Penguin Books 2009), 161-171.

5 'J.C. Beaglehole some personal reflections' supplement to the VUW Gazette No.11, 1971.
} 
a keen eye for quality, such as fine press prints and leather bound box sets. Beaglehole's mother however was a keen reader and would often leave passages open for her children to come upon when roaming about the house. ${ }^{6}$ His parents represent two sides to Beaglehole's book collecting habits. He was a discerning book collector as well as a prolific reader. In 1920 at the age of 19, he wrote a letter to his friend and possible sweetheart Star Hooper. In it Beaglehole reveals a love for books that infects his mind and ambitions. "As Augustine Birrel says, no private library can be considered respectable unless it consists of at least 10,000 volumes; so I will have to buy about 300 books a year. So I am afraid no prospective mother-in-law will ever have to worry about getting a sufficient return in wedding presents for the money spent over my nuptials."7

Today the collection of books that Beaglehole left behind contains 767 books, not including his fine press collection, which are identified by Beaglehole signing his name and date of acquisition within the front cover. There are 46 books that contain his marking but do not state dates. Thirteen of these can be assumed to be from around 1920 judging by his handwriting, the remaining 33 contain his name but no date. This habit of signing the books can be traced back to his father who would list and sign the books he owned. Beaglehole recalls the first book he purchased: "It was an odd volume of the Tatler vol.II, ${ }^{8}$ a little crown octavo thing, bound in paneled leather, blind-stamped, gilded spine and (once) edges, 1733, 9d. Romance. I see I wrote my full name on the fly-leaf, and the sacred date, 26/01/1917. Just think - 1733! It may have been to make this article look even more antique that I repeated my name on the inside cover, in my best writing, with the words 'Hys Booke."'From the first book he purchased the ritual of signing books into his library continued till 1950. Additional to his signed collection is a separate collection of fine press books from private presses such as Gregynog, Shakespeare Head, Nonesuch Press and Golden Cockerel Press. These books remain unsigned by Beaglehole as they were considered to be works of art and should not be marked. The titles in Beaglehole's fine press collection relate to his signed collection with prized authors such as Edward Thomas appearing in both collections and contains fine editions from publishers and printers in his signed collection. The impression is that even his unmarked fine press books were read as well as admired.

The journal Beaglehole kept from the years 1918 to 1926 gives a glimpse of his collecting and reading habits. On average he read 96 books per year, ${ }^{9}$ most were non-fiction, and in the first three months of 1919 Beaglehole listed books he had read as well as books he purchased. From January through March he read twenty-seven books and purchased fifteen. Of these fifteen books he purchased he read seven of them within a single month. From this small glimpse into his reading and buying habits it is possible to extrapolate Beaglehole, unlike other more stereotypical collectors, ${ }^{10}$ would read the books he purchased rather than

\footnotetext{
${ }^{6}$ Tim Beaglehole, A life of J. C. Beaglehole: A New Zealand Scholar. (Wellington: Victoria University Press, 2006), 55.

${ }_{8}^{7}$ JCB to Star Hooper, October 24th 1920.

8 Tim Beaglehole, A life of J. C. Beaglehole: A New Zealand Scholar. (Wellington: Victoria University Press, 2006), 55.

${ }^{9}$ Beaglehole read 80 books in 1920, 91 books in 1921, 100 books in 1922, 85 books in 1923, 109 books in 1924 and 116 books in 1925 .

10 "Let me simply remind you of that reply that, again, [Anatole] France held in readiness for those philistines who, having admired his library, rounded matter off with the obligatory question: 'And you've read all these, Mr France?' 'Not one tenth of them. Do you dine every day off your Sévres?'”, Benjamin, Walter. 'Unpacking My Library' from One Way Street: And Other Writings, (England: Penguin Books 2009), 164.
} 
hoarding them on shelves. This would also imply that Beaglehole carefully scrutinised his selection of books, since he was purchasing them with the intention of reading them.

Beaglehole's library has changed over the years as his letter to Star Hooper shows. Beaglehole states that in October 1920 his library contained 250 books, not including periodicals or concert programs. ${ }^{11}$ In the list of Beaglehole's library as it exists today, that contains 767 books acquired throughout his lifetime, only 25 books can be confirmed to be in his collection in 1920. This fact shows that over the years there has been cutting and culling. This would partially be due to the second hand book culture of New Zealand at that time where books were often resold in order to be able to acquire different books. ${ }^{12}$ This would imply that the collection of Beaglehole's earlier library of books that still remains part of his library is compiled of books Beaglehole could not throw away, making it a distilled collection of irreplaceable books that has remained with Beaglehole over his lifetime.

\section{Graph Results}

Breaking down Beaglehole's library collection reveals specific qualities that correlates to his personal life. Using Ggobi, ${ }^{13}$ a high dimensional graphing program, the data from Beaglehole's collection is visualised into plotted graphs. Ggobi allows easy comparison between different data sets, and can retain the characteristics of a value. The software has been used to plot characteristics against the year that a book was acquired, giving context to the graph in relation to Beaglehole's life. Each book within the collection is represented by a point that is plotted on an x-axis and y-axis. Each point contains tag data so that the specific book and its characteristics can be identified. The values plotted are divided into two types, categories and variables. The categories are data that have no numeric value but rather include information such as authors, publishers and location of publication. Categories are plotted by the program on the y-axis by adding a y value every time a new category is introduced. So the y-axis shifts that appear show new categories added to the collection. The variables are time based figures; date of acquisition and the date of publication. These graphs when viewed holistically show trends over the life of the collection and reveal a broader picture of the relationship between Beaglehole and his books.

\footnotetext{
${ }^{11}$ JCB to Star Hooper, October 24th 1920.

12 Anna Rogers and Max Rogers, "Introduction: So Many Bookshops," in Turning the Pages: The Story of Bookselling in New Zealand. (Auckland: Booksellers New Zealand, 1993), 1-15.

13 http://www.ggobi.org/.
} 


\section{Number of Books purchased per Year against Date of Acquisition}

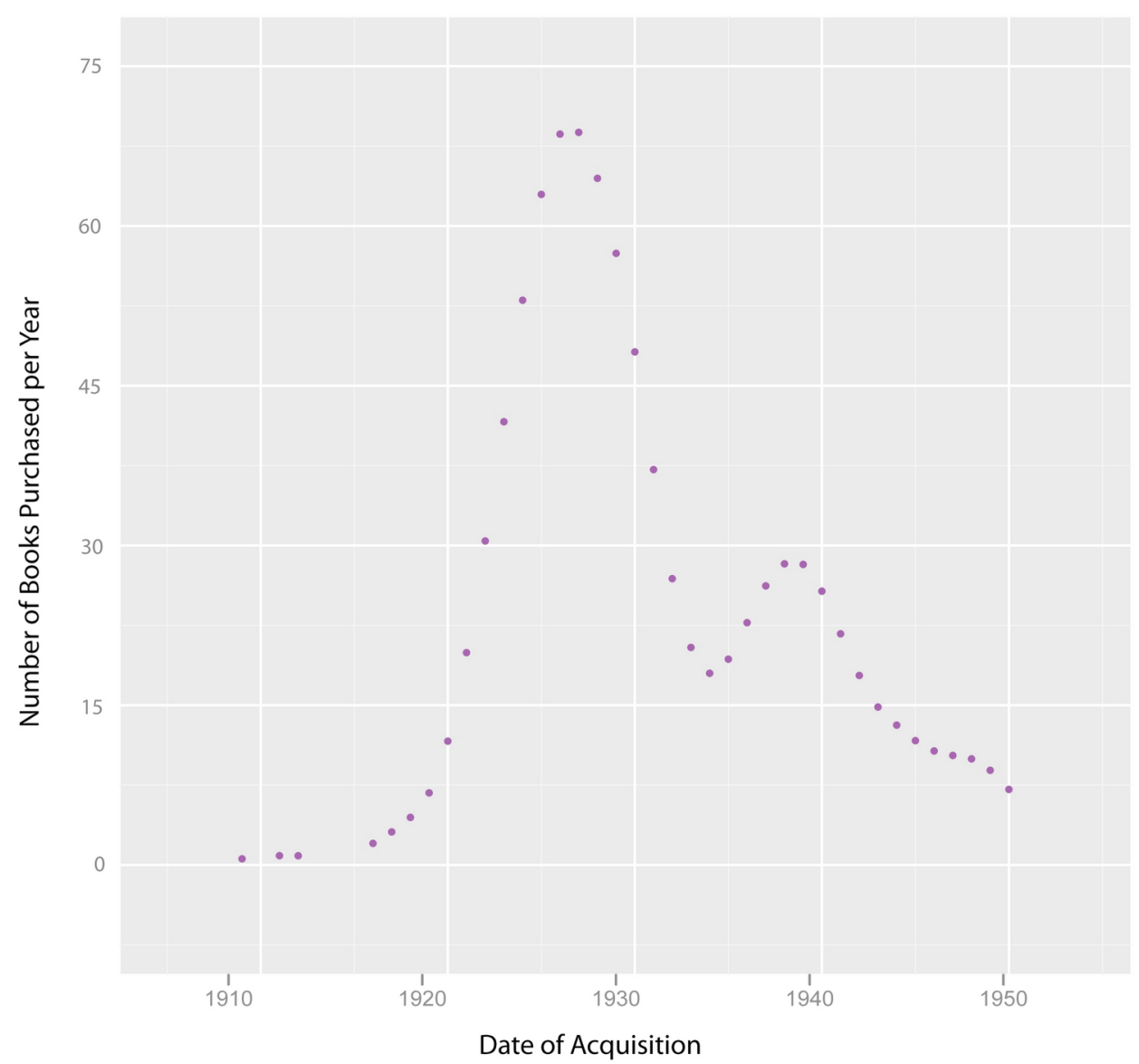

Figure 1: A Generalised Linear Curve Showing the Number of Books Purchased per Year

The graph above displays a linear plot of the date of acquisition against the number of books purchased in that year (fig. 1) revealing a trend that correlates, not to all the books purchased in his life, but to the periods of his life where the books purchased have remained in the collection. The beginning of the plot displays childhood books that have remained with him through out his life. The earliest is a books entitled Wood Magic by Richard Jeffries ${ }^{14}$ and inside the front cover it is signed "Jack, from Mother June $13^{\text {th }} 1909$." It was not until The Tatler Vol. II that Beaglehole started purchasing books and so prior to this, only seven books from Beaglehole's early library remain in the collection today. The graph shows a jump around the period of 1926 to 1929. Beaglehole lived in London during this period of time, where he was exposed to new ideas and to a larger selection of books from around the world. This period of Beaglehole's life is considered to have influenced his ambitions academically

\footnotetext{
${ }^{14}$ Richard Jeffries, Wood Magic, (London: Longmans, Green, and Co., 1907).
} 
and politically, as the city around him was teemed with activity and London is where Beaglehole made lifelong friends and met his influential mentor Harold Laski. In Beaglehole's letters to his family, Laski is mentioned in the highest regard, and Laski's attitudes towards education and politics echoed in Beaglehole's life after London. The young impressionable New Zealander must have remembered this period of his life well, as his return visit in 1949 sees a jump in books purchased where the signing inside the covers is reminiscent of his earlier trip. The sizable valley that develops in the early to mid 1930's accurately shows a period in Beaglehole's life where the great depression was taking its toll on New Zealand academia and where Beaglehole's political view points made finding a job in a conservative New Zealand difficult. Beaglehole's lower income during this period of time as well as the responsibilities of being newly married to his wife Elsie, made this period financially more difficult to purchase new books, though it is during this lull that Beaglehole started work on the Cook journals, a work that would in a way bring an end to his collection in 1950. As his work became more acclaimed and as Beaglehole became more respected in academia he was overloaded with books given as gifts or submissions to be critiqued, generally creating a much larger workload. 


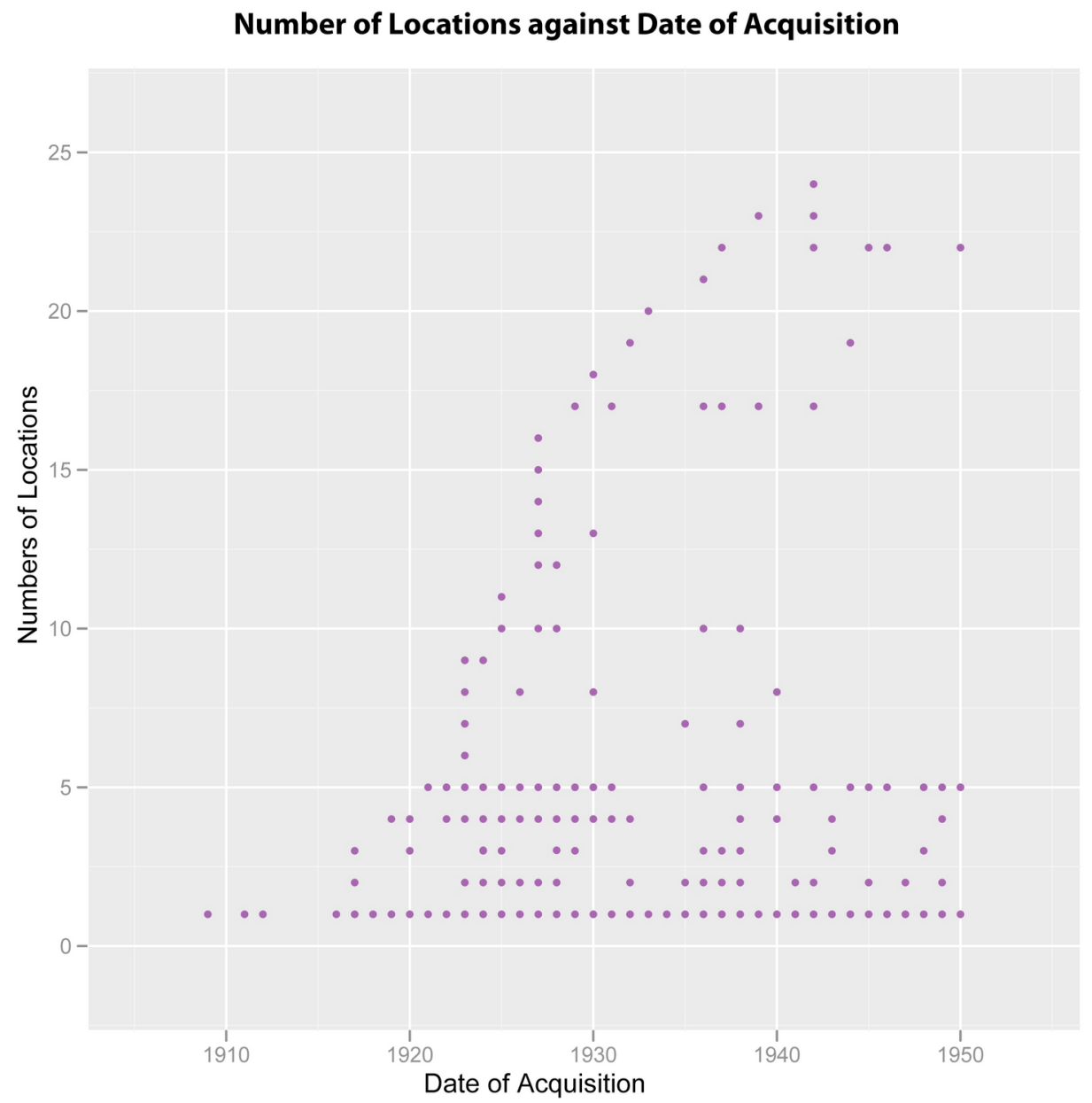

Figure 2: Graph Showing the Number of Location Against the Date of Acquisition. The Lower Five Hozontal Lines Show the Location (in Ascending Order) London, Cambridge, Wellington, Oxford and New York

The above graph displaying Location against the Date of Acquisition (fig. 2) shows more about the availability of books to Beaglehole rather than any insight into his relationship to his books. There is clearly a rise of new book source locations from which books are acquired for Beaglehole's collection during the London period of his life, but the bulk of the points on the graph remain at the bottom demonstrating that books that were purchased early in his life were consistent throughout and in the later life of the collection the locations became more varied. This graphic representation demonstrates the state of the book trade and availability to Beaglehole, particularly in New Zealand. The bottom five horizontal lines represent London, Cambridge, Wellington, Oxford and New York. All of these places were publishing and printing centers that were active in the New Zealand book market in the early to mid 
1900 's and produced books that were of specific interest to Beaglehole. ${ }^{15}$ This trend in conjunction with the upper part of the graph shows that most of the books in the collection were available locally, though Beaglehole did seem to take advantage of other opportunities for acquiring books when they arose.

The Date of Publication against Date of Acquisition

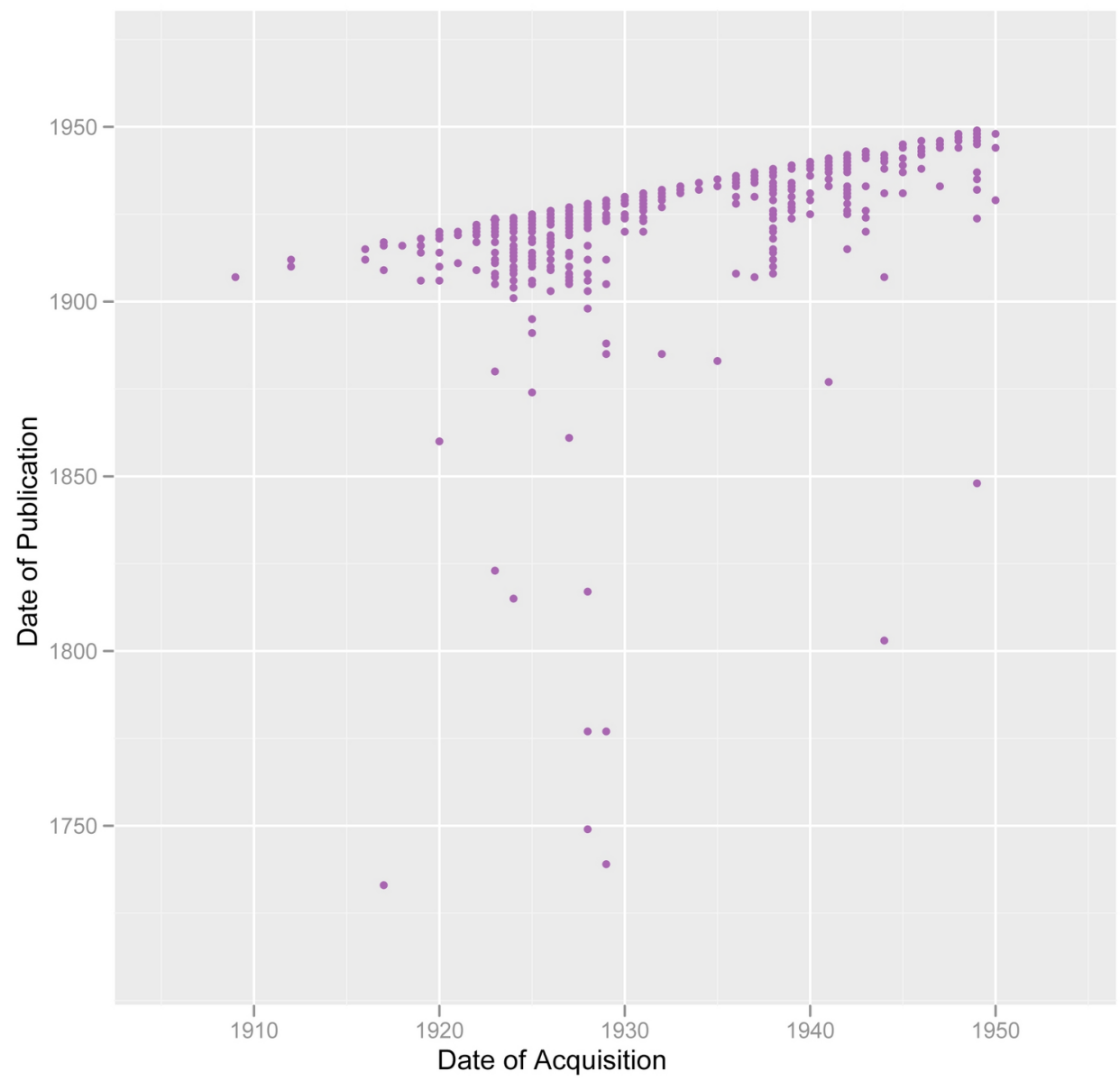

Figure 3: Graph Displaying the Date of Publication against the Date of Acquisition. The Upward Trend Shows that Book were Often Acquired Close to their Publication

The date when the books in Beaglehole's collection were printed (fig 3.) shows the age of the object compared to when he purchased them. In the graph above there is a strong trend line showing books were often bought close to their publishing date, generally within a year or two of publication but there are a handful of older books that contrast with the general trend. Beaglehole at that time was keen to acquire new books and new ideas, yet on the un-

\footnotetext{
${ }^{15}$ Ross Harvey et al., Book \& print in New Zealand : a guide to print culture in Aotearoa. (Wellington: Victoria University Press, 1997), 159-160.
} 
derside of the main trend there are falls showing instances where Beaglehole purchased older books. Clustering occurs around the periods of 1926 to 1929 and a gap is apparent in the early 1930's consistent with the other graphs. London's bookshops seemed to offer more than those in Wellington and a bookshop Beaglehole frequented in London, Bumpus Books, was both a secondhand dealer and a fine press outlet as well as selling general books. Offering a wide selection of books Beaglehole would often browse and haggle here for new acquisitions for his collection. ${ }^{16}$

The graph of book authors collected by Beaglehole plotted against the year they were obtained (Fig. 4) shows some favour and loyalty to certain authors but but only in a few cases. The acquisition of books during periods of some prosperity show vertical lines, indicating the significant increase in the amount of new authors collected during those periods of time. This suggests that Beaglehole was open to new and unfamiliar ideas and had an open mind when it came to selecting books. The graph correlates with Fig. 1 in that there is a sharp increase in new authors during the 1926 to 1929 period and the graph displays a similar lull during the Great Depression. With over 500 different authors represented out of 767 books the majority of the collection is not necessarily dedicated to any specific author. Yet the most frequent authors hold interesting characteristics. Edward Thomas, a wartime poet, that Beaglehole's journal show he was reading when he was only eighteen years of age, and Thomas is the most frequent author in the collection. Multiple copies of Thomas's collected works in the library encourage the conclusion that, for Beaglehole, adding a book to his collection was, in itself a form of respect. The mentor of Beaglehole's mentor in London, Harold Laski, ${ }^{17}$ features quite prominently within the collection. With the first of Laski's book purchased in 1924, before the two met in 1927 Beaglehole obviously knew of Laski. Later in 1929 an unusual note on the inside of $A$ tract on the law of nature and principle 18 by Granville Sharp reads "J.C. Beaglehole, Given to me by Laski 31 January 1929." The signing is unusual as there are is no other book in the collection that Beaglehole has inscribed, mentioning that it was gifted to him. These examples demonstrate both Beaglehole's openness to new ideas through the wide variety of authorship represented, and his preference for certain authors through either the numbers of their books that are represented, or his preferential treatment of those books, as in the aforementioned inscription.

\footnotetext{
${ }^{16}$ JCB to Parents, 7 September 1928 (NZETC).

17 Tim Beaglehole, A life of J. C. Beaglehole: A New Zealand Scholar. (Wellington: Victoria University Press, 2006), 95-96.

${ }^{18}$ Sharp, Granville. A Tract on the Law of Nature and Principle, (London: B. White. 1777).
} 


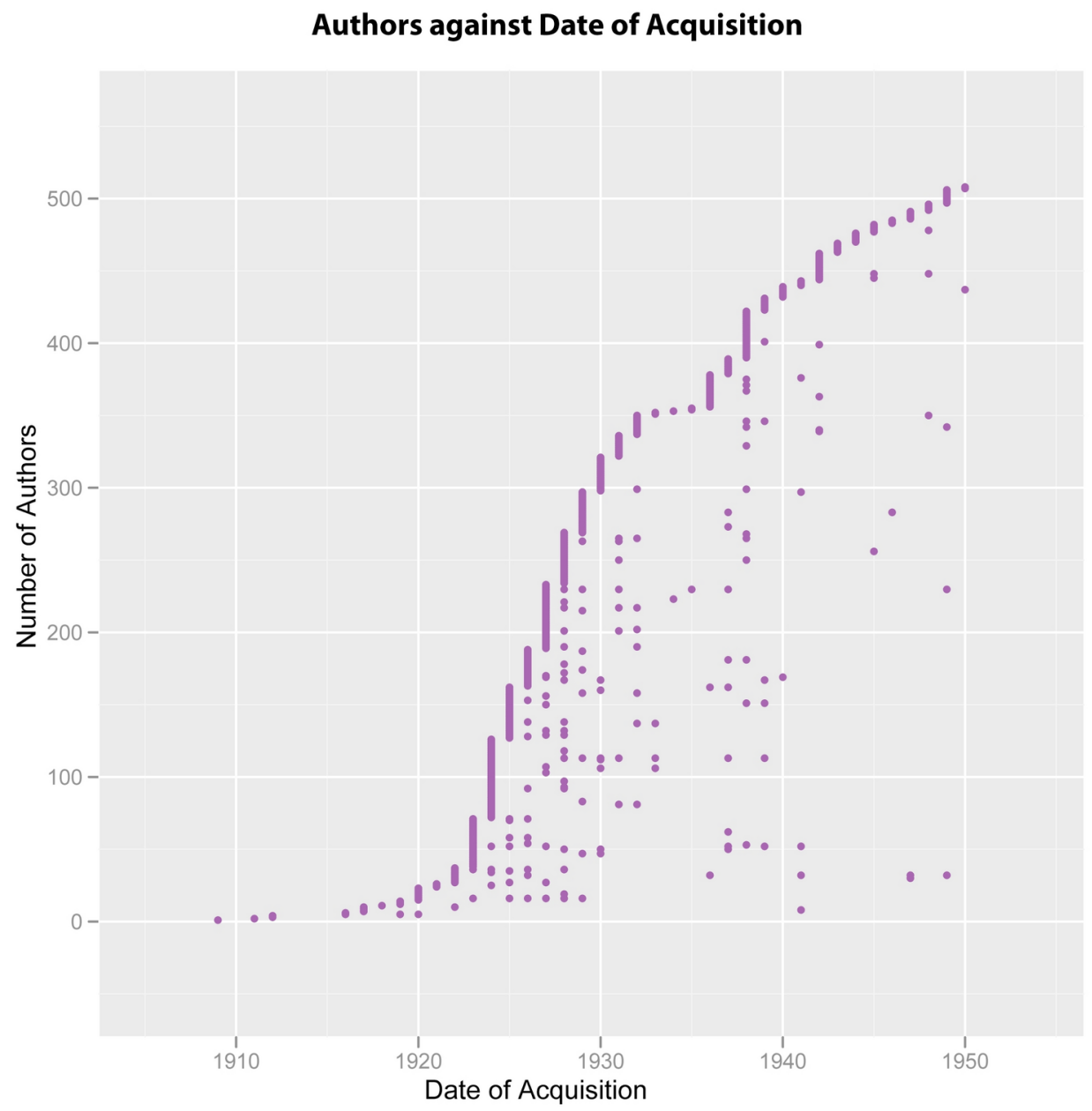

Figure 4: Graph Displaying the Number of Authors against the Date of Acquisition

The graph of publishers (fig. 5) relates to the graph of authors in that it shows a similar trend of new ideas and periods in Beaglehole's life. Publishers however, reflect another aspect of his book collection, that of brand and a mark of quality. The lower portion of the graph contains clusters of horizontal trends. Like the location graph (fig. 2) these show that these particular publishers are consistent through the duration of the life of the library. Notably J.M. Dent and the Traveler's library series, that were affordable and often printed well known authors and works, is common in the collection. Oxford University Press, Cambridge University Press and Clarendon Press are the most abundant publishers and were usually affordable. These presses are also associated with reputable academic institutions. Beaglehole had the hope of having his thesis published by Oxford University press in $1929,{ }^{19}$ a publisher of whom Beaglehole thought very highly. The trend of authors and publishers displayed in

${ }^{19}$ JCB to Parents, 5 April 1929 (NZETC). 
these graphs displays over 600 different authors and over 150 publishers, a wide range for a collection of 767 books. The absence of any dedicated authors or publishers suggests that this collection exists primarily for the ideas contained inside the books. When trends shown by the graphs are compared to events in his life, it becomes clear that sharp inclines mark periods of increased representation of new ideas within the collection. In conjunction with the ownership of these books one can not help but consider the notion that the books are representative of ideas shared by Beaglehole cemented in ink and paper.

\section{Number of Publishers against the Date of Acquisition}

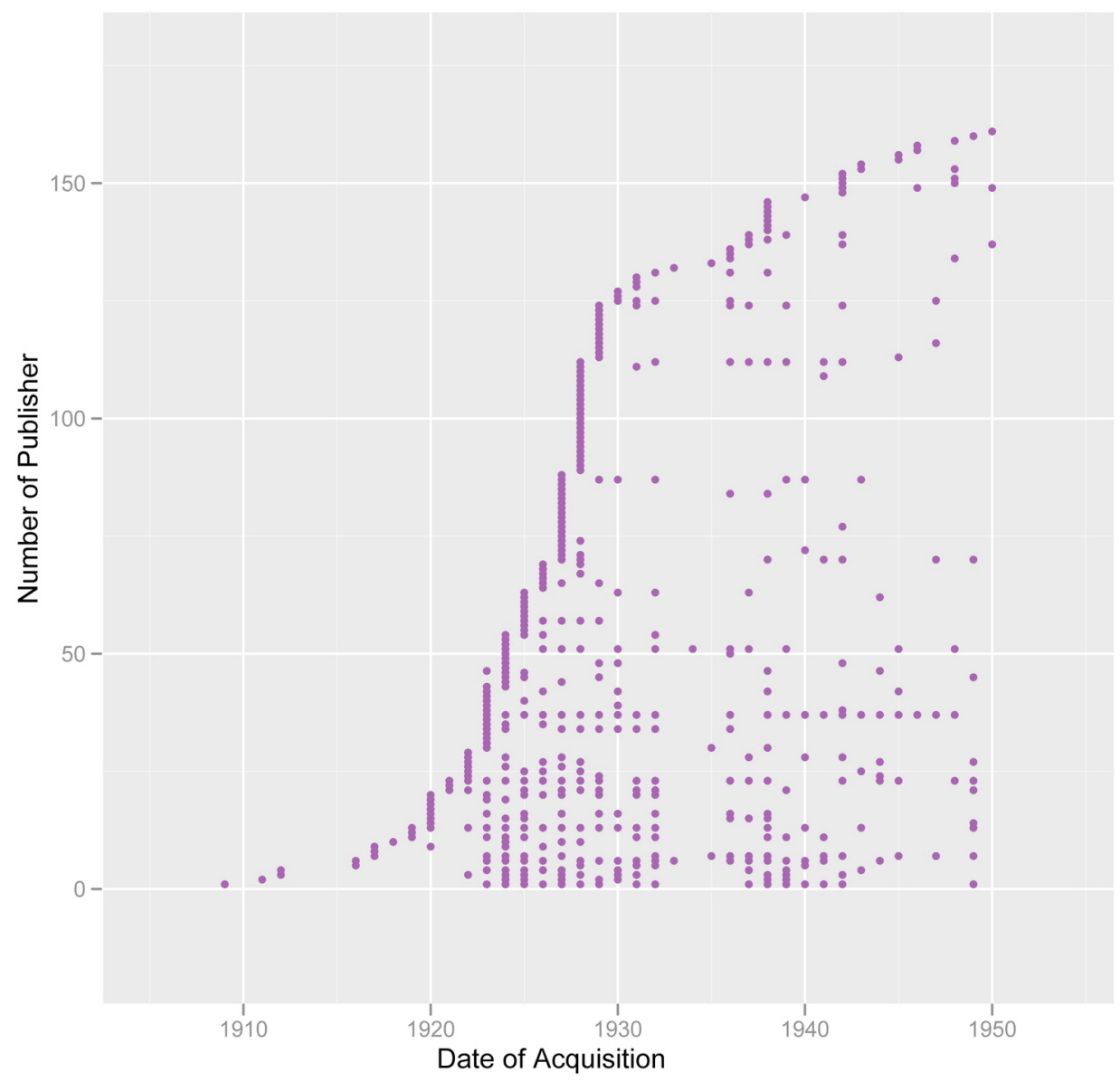

Figure 5: A Graph Displaying the Number of Publishers Against the Date of Acquisition. Note the Cluster Around the Bottom of the Graph Showing a Trend of Consistent Publisher in the Collection 


\section{Conclusion}

The graphs of Beaglehole's library show no outright trend shared by the books in his library. All the graphs showed a scatter rather than strong trends relating to authors, publishers or age. There is no definitive reason within the graphs for why these books were gathered together into Beaglehole's collection. Yet the graphs illustrate a complex and unique relationship between Beaglehole and his irreplaceable books. These books remain in Beaglehole's collection because of the ideas they represent for Beaglehole. However, it was not just the ideas embodied in the text within his books that were important to Beaglehole. His books also symbolised other ideas, such as memories, passions or ideals. The graphs show patterns that relate to Beaglehole's personal life as well. Beaglehole's pattern of collecting books appear to mould around events and periods of his life. The London years of 1926 to1929 with the accompanying increases of new books show a period where Beaglehole acquired and read books that he could not access before. These books contained new thoughts that have travelled half way around the world with him and remained with Beaglehole over the course of his life.

This paper investigates a collection that is relevant to book history and Beaglehole's biographers though the wider scope of the research may also serve designers of books as objects and even developers of ebooks and electronic reading devices. The relationship that existed between Beaglehole and his books is both remarkable and unique. There lack any clear reasons as to why these specific books were all brought together by Beaglehole, although the reasoning behind Beaglehole's choices do become more transparent with careful examination of Beaglehole's letters, journal and biography. A closer look at the collection frames something very human and unique that should not be forgotten, the emotive and intimate relationship between a collector and his books. A greater understanding of these powerful relationships that shape lives helps to answer the questions as to how we can make the reading experience better and how to retain the indefinable connection of owning a book even as books continue to evolve and change in this new digital age. Each book in anyone's library has unique reasons as to why it is in the collection. Whether its importance rests in its binding, its author, the ideas between the books covers, the texture of the paper it is printed on or the lingering scent that rouses a memory. Factors such as these should be kept in mind when analysing the history of books and readers or creating new works for future readers so that the experience between the reader and text may be as rich as the experiences of John Cawte Beaglehole.

\section{References}

Beaglehole, Tim. A Life of J.C Beaglehole: A New Zealand Scholar. Wellington: Victoria University Press, 2006.

Benjamin, Walter. 'Unpacking My Library' in One Way Street: And Other Writings. England: Penguin Books 2009.

Chartier, Roger. "Labourers and Voyagers: From the Text to the Reader" in The Book History Reader. London: Routledge, 2002.

Chartier, Rodger. The Order of Books. Oxford: Polity Press, 1992.

Csikszentmihalyi. Mihaly, and Eugene Rochberg-Halton, The Meaning of Things: Domestic Symbols and the Self. Cambridge: Cambridge University Press, 1981.

Griffith, Penny and Ross Harvery and Keith Maslen. Book and Print in New Zealand. Wellington, Victoria University Press, 1997. 
J.C. Beaglehole Some Personal Recollections: Supplement to the [Victoria University] Gazette, contributions by Tim Beaglehole, Harold Miller, James Bertram, Mary Boyd, W.J. Scott, Fred Page and Jim Campbell. no.11, 1971.

Howsam, Leslie. Old Books \& New Histories: An Orientation to studies in Book and Print Culture. Toronto: University of Toronto Press, 2006.

Iser, Wolfgang. The Act of Reading. Baltimore: John Hopkins University Press, 1978.

McKenzie, D.F. Bibliography and the Sociology of Texts. Cambridge: Cambridge University Press, 1999.

Munro, Doug. 'J.C. Beaglehole: Public Intellectual, Critical Conscience', in The Ivory Tower and Beyond: Participant Historians of the Pacific. Newcastle: Cambridge Scholars Publishing, 2009.

Norman, Donald. Emotional Design: Why we Love (or Hate) Everyday Objects. New York: Basic Books, 2005.

Rodgers, Anna and Max Rodgers. 'Introduction: So Many Bookshops' in Turning the Pages: The Story of Bookselling in New Zealand. Auckland: Booksellers New Zealand, 1993.

Shep, Sydney. 'The Centennial Racket: J.C Beaglehole, Nationalism and the 1940 New Zealand Centennial Publications' in Literary Cultures and the Material Book, 387-398. London: British Library, 2007.

\section{About the Author}

Dan Scudder

Dan Scudder is an industrial design graduate currently working on his Master of Design while also working in a $\mathrm{CNC}$ manufacturing plant. His topic focuses on the book as an object and is researching how the book can be integrated into future manufacturing technologies. $\mathrm{He}$ is greatly interested in the design potential of the book and its place in future society. Dan believes that the book offers something irreplaceable to society and intends to pin point what that is. 
Copyright of International Journal of the Book is the property of Common Ground Publishing and its content may not be copied or emailed to multiple sites or posted to a listserv without the copyright holder's express written permission. However, users may print, download, or email articles for individual use. 